\title{
Article \\ Accumulation and Phytotoxicity of Two Commercial Biocides in the Lichen Evernia prunastri and the Moss Brachythecium sp.
}

\author{
Andrea Vannini ${ }^{1}$, Giulia Canali ${ }^{1}$, Sergio Enrico Favero-Longo ${ }^{2}$ and Stefano Loppi ${ }^{1, *(\mathbb{C})}$ \\ 1 Department of Life Sciences, University of Siena, 53100 Siena, Italy; andrea.vannini@unisi.it (A.V.); \\ giulia.canali@student.unisi.it (G.C.) \\ 2 Department of Life Sciences and Systems Biology, University of Turin, 10125 Turin, Italy; \\ sergio.favero@unito.it \\ * Correspondence: stefano.loppi@unisi.it
}

check for

updates

Citation: Vannini, A.; Canali, G.;

Favero-Longo, S.E.; Loppi, S.

Accumulation and Phytotoxicity of

Two Commercial Biocides in the

Lichen Evernia prunastri and the Moss

Brachythecium sp. Stresses 2021, 1,

69-77. https://doi.org/10.3390/

stresses 1020006

Academic Editor: Luigi Sanita' di

Toppi

Received: 24 March 2021

Accepted: 7 April 2021

Published: 12 April 2021

Publisher's Note: MDPI stays neutral with regard to jurisdictional claims in published maps and institutional affiliations.

Copyright: (c) 2021 by the authors. Licensee MDPI, Basel, Switzerland. This article is an open access article distributed under the terms and conditions of the Creative Commons Attribution (CC BY) license (https:// creativecommons.org/licenses/by/ $4.0 /)$.

\begin{abstract}
This study investigated the accumulation and phytotoxicity of two commercial biocides widely used for the removal of biological colonization from monuments, namely Biotin $\mathrm{T}^{\circledR}(3 \%)$ and Preventol RI80 ${ }^{\circledR}(2 \%)$, on lichen and moss model species, specifically, Evernia prunastri and Brachythecium sp. The active compounds, benzalkonium chloride (BAC) for Preventol RI80 and isothiazolinone (OIT) for Biotin T, were accumulated in similar amounts in both species without significant changes for up to 21 days. Both compounds caused a severe impairment of the photosynthetic apparatus of these species, without any recovery over time, although Biotin T showed a faster and stronger action, and the moss was more sensitive than the lichen. By shedding light on the accumulation of BAC and OIT in lichens and mosses and quantifying their effectiveness to photosynthetically devitalize these organisms, the obtained results are a useful comparison for the implementation of green alternative products for the control of biodeteriogens.
\end{abstract}

Keywords: benzalkonium chloride; biocidal compounds; n-octyl-isothiazolinone; photosynthesis; uptake

\section{Introduction}

Biodeterioration of monumental surfaces is one of the most critical issues for the conservation of cultural heritage [1]. Among organisms involved in this process, lichens and mosses are macroscopically evident [2]. Lichens cause physical and chemical deterioration by means of hyphal penetration and the release of several acidic compounds (carbonic acid, acid polysaccharides, oxalic acids, and other acids) at the rock-lichen interface [3,4]. Mosses also penetrate with their rhizoids and can leach and detach minerals from stony surfaces [5,6], thus causing structural weakening, especially on porous stones [7]. Although mosses are less common than lichens on sunny and dry surfaces, and for this reason only the removal of lichens has attracted diffuse experimental interest of restorers, they can be also effective in damaging monumental surfaces [8].

Currently, although the research on the removal of biological colonization on monuments with non-chemical or chemically green alternatives is well active and promising $[9,10]$, biocidal products still occupy a prominent position for this purpose in practical use by restorers [11]. Specifically for lichens, their effectiveness is well proven [12-14], and a comprehensive overview of their efficiency and limits was recently proposed by Favero-Longo et al. [15], following the treatment of common saxicolous crustose lichens (Protoparmeliopsis muralis and Verrucaria nigrescens) during field experiments. Additionally, their effectiveness was later confirmed by the exposure of the lichen Xanthoria parietina under controlled conditions [16], and more recently, following the treatment of the lichen Xanthoparmelia tinctina to compare different application protocols [17]. In contrast, information on the effectiveness of biocidal compounds on mosses is limited to a few studies [14,18], even if specific commercial products for their removal are available [19]. 
Although biocides are generally effective for the removal of lichens, their efficiency should not be taken for granted, since nonfunctional applications were also observed [20]. Failure of full lichen devitalization is probably related to a different translocation of the biocide inside the thallus, suggesting that different lichens may need different doses of the active principle to become efficiently devitalized. However, information about the toxic threshold of biocides to lichens is almost missing, and the only available data are related to the accumulation of benzalkonium chloride [17], suggesting an opportunity for further studies in this field to optimize the effectiveness of their practiced-although increasingly discouraged-application, and as a model for the ongoing set-up of alternative strategies with green products. Currently, among biocides, quaternary ammonium compounds and isothiazolinone compounds are two of the most commonly used active ingredients of biocidal products, thanks to their high effective biocidal action on microorganisms [7,21-23], and are therefore excellent candidates for a first exploration on this topic.

The aim of this study was to investigate the accumulation and the damage to the photosynthetic apparatus driven by two commercial biocides widely used for the removal of biological colonization from monuments, namely Biotin $\mathrm{T}^{\circledR}$ and Preventol RI80 ${ }^{\circledR}$, on lichen and moss model species, specifically, Evernia prunastri and Brachythecium sp., after 1,3, and 21 days from their exposure.

\section{Results}

The lichen Evernia and the moss Brachythecium accumulated similar amounts of benzalkonium chloride (BAC) and n-octyl-isothiazolinone (OIT), and without significant changes over time (Figure 1).

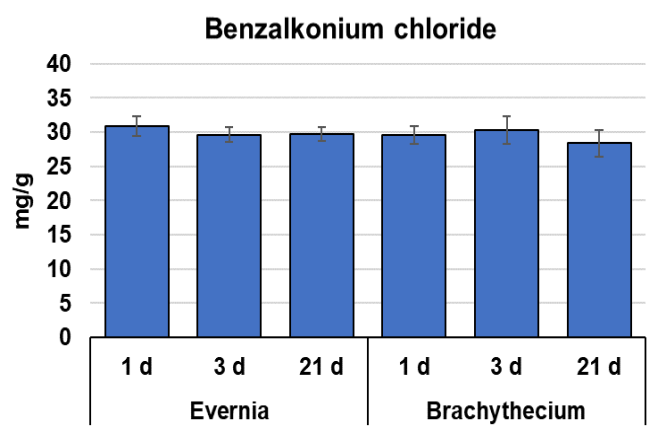

(a)

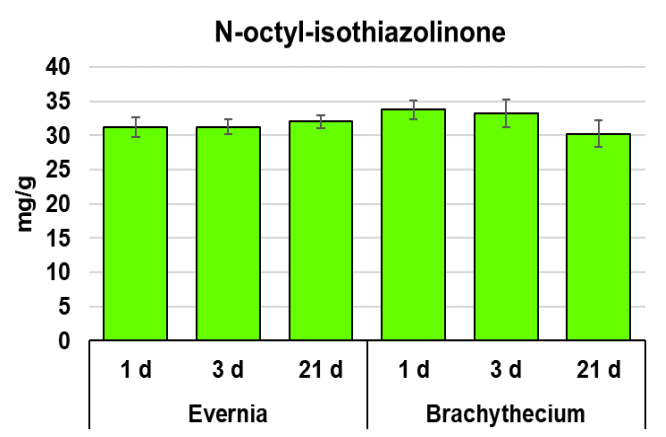

(b)

Figure 1. Concentration (mean \pm standard error) of benzalkonium chloride (a) and n-octyl-isothiazolinone (b) in samples of Evernia and Brachythecium after 1, 3, and 21 days from exposure with Biotin T and Preventol RI80. Statistically significant differences $(p<0.05)$ did not emerge either over time or between species.

Compared with control samples, Biotin R and Preventol RI80 caused a strong impairment of the photosynthetic apparatus in both the lichen and the moss (Table 1). After 1 day, Evernia showed a mean decline in chlorophyll content and normalized difference vegetation index (NDVI) of $43 \%$ and $28 \%$, respectively, while Brachythecium showed $74 \%$ and $41 \%$, respectively. In both species, chlorophyll a fluorescence parameters were already almost zeroed after 1 day, as clearly shown by the analysis of the OJIP transient profiles (Figure 2), which showed that very strong damage occurred at the photosynthetic apparatus of both organisms, with treated samples showing the complete loss of their OJIP step profile, irrespective of treatment. As a matter of fact, here we present only the data of one parameter, the common indicator of photosynthetic efficiency $\mathrm{F}_{\mathrm{V}} / \mathrm{F}_{\mathrm{M}}$, which is widely used to obtain functional information of the photosynthetic apparatus following biocidal treatments $[13,15-17,24]$. After 3 days, both Evernia and Brachythecium showed further reductions in the content of chlorophyll, except for the Brachythecium treated with Preventol RI80. NDVI was unchanged, with only the exception of Brachythecium treated with Biotin 
T. After 21 days, both biocides caused a zeroing of the chlorophyll content and a further reduction of NDVI compared with control samples of ca. $52.5 \%$ for Evernia and $75 \%$ for Brachythecium.

Table 1. Expression of the physiological parameters (mean ratio between treated and control samples \pm standard error) in samples of E. prunastri and Brachythecium sp. after 1, 3, and 21 days from exposure with Biotin T and Preventol RI80. * statistically significant $(p<0.05)$ differences between exposed and control samples; different letters indicate statistically significant $(p<0.05)$ differences over time; bold indicates differences between biocidal treatments for the same exposure of time; underlined indicates differences between Evernia and Brachythecium for the specific biocide at the same time of exposure.

\begin{tabular}{|c|c|c|c|c|c|}
\hline & \multirow[b]{2}{*}{ Days } & \multicolumn{2}{|c|}{ Evernia } & \multicolumn{2}{|c|}{ Brachythecium } \\
\hline & & Biotin T & Preventol & Biotin $T$ & Preventol \\
\hline \multirow{5}{*}{$\begin{array}{l}\text { Chlorophyll } \\
\text { content }\end{array}$} & 1 & $0.56 \pm 0.01 * a$ & $0.59 \pm 0.01 * a$ & $0.18 \pm 0.00 * a$ & $0.34 \pm 0.01 * a$ \\
\hline & 3 & $0.05 \pm 0.00 * b$ & $0.29 \pm 0.01 * b$ & $0.10 \pm 0.01 * b$ & $0.35 \pm 0.01 * a$ \\
\hline & 21 & $0.00 \pm 0.00 * \mathrm{c}$ & $0.00 \pm 0.00 * \mathrm{c}$ & $0.00 \pm 0.00 * \mathrm{c}$ & $0.00 \pm 0.00 * b$ \\
\hline & & \multicolumn{2}{|c|}{ Evernia } & \multicolumn{2}{|c|}{ Brachythecium } \\
\hline & days & Biotin T & Preventol RI80 & Biotin T & Preventol RI80 \\
\hline \multirow{5}{*}{ NDVI } & 1 & $0.70 \pm 0.02 * a$ & $0.73 \pm 0.02 * a$ & $0.55 \pm 0.01 * a$ & $0.63 \pm 0.01 * a$ \\
\hline & 3 & $0.76 \pm 0.02 * a$ & $0.69 \pm 0.01^{*} a$ & $0.46 \pm 0.01 * b$ & $0.63 \pm 0.01 * a$ \\
\hline & 21 & $\overline{0.49 \pm 0.01 * b}$ & $\overline{0.46 \pm 0.01^{*} \mathrm{~b}}$ & $\overline{0.22 \pm 0.00 * c}$ & $\overline{0.28 \pm 0.00 * b}$ \\
\hline & & \multicolumn{2}{|c|}{ Evernia } & \multicolumn{2}{|c|}{ Brachythecium } \\
\hline & days & Biotin T & Preventol RI80 & Biotin T & Preventol RI80 \\
\hline \multirow{3}{*}{$\mathrm{F}_{\mathrm{V}} / \mathrm{F}_{\mathrm{M}}$} & 1 & $0.05 \pm 0.00 *$ & $0.04 \pm 0.00 *$ & $0.07 \pm 0.00 *$ & $0.05 \pm 0.00 *$ \\
\hline & 3 & $0.07 \pm 0.00 *$ & $0.05 \pm 0.00 *$ & $0.05 \pm 0.00 *$ & $0.05 \pm 0.00 *$ \\
\hline & 21 & $0.05 \pm 0.00 *$ & $0.10 \pm 0.00 *$ & $0.06 \pm 0.00 *$ & $0.06 \pm 0.00 *$ \\
\hline
\end{tabular}
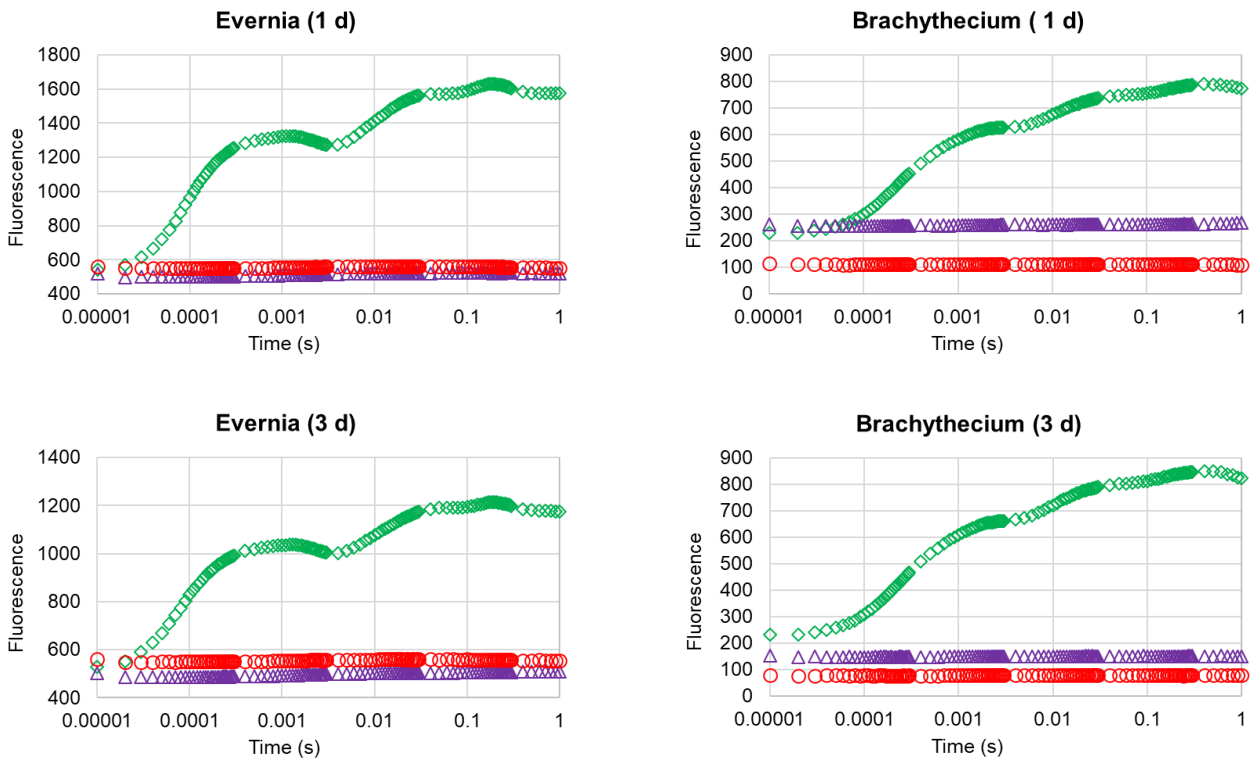

Figure 2. Cont. 


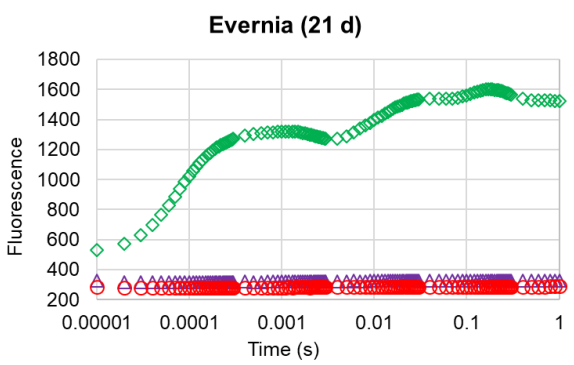

(a)

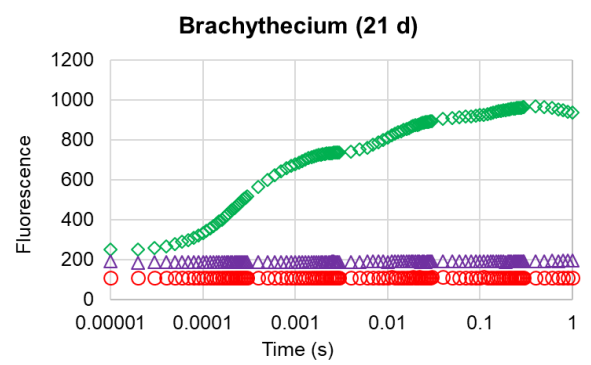

(b)

Figure 2. OJIP transient curves of Evernia (a) and Brachythecium (b) after 1, 3, and 21 days from exposure with water (control; green diamonds), Biotin T (blue triangles), and Preventol RI80 (red circles).

The analysis of the OJIP transient profiles (Figure 2) confirmed the strong damage occurred at the photosynthetic apparatus of both investigated organisms, with treated samples showing the complete loss of their OJIP step profile, irrespective of treatment.

\section{Discussion}

BAC and OIT were clearly and irreversibly (at least for 21 days) accumulated inside the selected model species, likely owing to the ability of these compounds to interact with and diffuse through cell membranes $[25,26]$. Considering the concentration of these active compounds in the exposure solution $(16 \mathrm{~g} / \mathrm{L}$ of BAC in the Preventol RI80 solution and $3 \mathrm{~g} / \mathrm{L}$ of OIT in the Biotin T solution), Evernia and Brachythecium showed an overall uptake of BAC of $0.26 \%$ and of OIT of $1.38 \%$. A five-fold higher OIT uptake suggests a remarkably higher interaction of this compound with cell membranes of our model organisms, which is consistent with the quick intracellular accumulation of this compound (2-10 min) previously observed in the bacterium Escherichia coli and the yeasts Saccharomyces cerevisiae and Schizosaccharomyces pombe $[22,27,28]$, which may reach peaks of $97 \%$ [27]. Efficient accumulations were also observed for BAC in E. coli, and the higher plants Lepidium sativum and Lactuca sativa [25,29], proportional to its availability in the exposure medium.

The lack of reduction in BAC and OIT during the experiment highlights their great stability, at least during the 21 days of the experiment and in the absence of environmental factors (e.g., rainfall) that could cause their release. BAC is a very stable family of xenobiotic compounds [30], which are mainly degraded as a consequence of the action of microorganisms, which can use it as substrate [31], but only when the concentration is below the threshold of $120 \mathrm{mg} / \mathrm{L}$ [32] (i.e., > 100 times lower than the selected exposure concentration of $16 \mathrm{~g} / \mathrm{L}$ ). Similarly, OIT is degraded by chemical, biochemical, and photochemical factors [26]. A lack of BAC and OIT reductions during the experiment may be linked to the suppression of growth on the tested organisms due to the high microbiological toxicity of these two compounds [33], even if OIT compounds are commonly reported to have a very short environmental persistence $\left(t_{1 / 2}=9\right.$ days) [34].

BAC concentrations detected in both Evernia and Brachythecium are ca. 10 times higher than those measured in the lichen $X$. tinctina following treatment with Preventol-enriched cellulose poultice, the most effective infield method in generating BAC accumulation and photosynthetic damage in lichens [17]. Despite this, both the exposure methodologies generated a very similar alteration on the photosynthetic efficiency of the investigated organisms, already after one day from the exposure, since their values fell below the viability threshold $\left(\mathrm{F}_{\mathrm{V}} / \mathrm{F}_{\mathrm{M}}=0.15\right)$ proposed by Favero-Longo et al. [15]. It is likely that the maintenance of thalli in wet conditions, ensured by both the batch incubation and the application with cellulose poultice, supported their physiological activity and sensitivity to the biocidal action [17], favoring the treatment effectiveness independently of the quantity of provided and accumulated compounds. In support of this view, a similar devitalization by the BAC-based biocide Preventol RI80 was also observed in two other 
studies conducted both in the field (using Preventol-enriched cellulose poultice) and under controlled conditions (using the soaking procedure). The former showed an impairment on the photosynthetic efficiency $\left(\mathrm{F}_{\mathrm{V}} / \mathrm{F}_{\mathrm{M}}\right.$ values $\left.<0.15\right)$ of the crustose lichens P. muralis and $V$. nigrescens after 21 days from their treatment [15], while the latter showed the complete injury of the photosynthetic system (i.e., the chlorophyll a fluorescence and chlorophyll content) of the foliose lichen Xanthoria paretina after 21 days from treatment, without a substantial recovery after 90 days from the exposure [16]. Moreover, similar damage to the photosystem II was observed by Tretiach et al. [13] for the lichen Acrocordia conoidea and Bagliettoa marmoreal after exposure to a solution containing $15 \mathrm{~g} / \mathrm{L}$ of BAC.

Biotin $\mathrm{T}$ revealed similar effectiveness to induce photosynthetic devitalization of lichens [15-17], and also to generate an efficient early devitalization of the moss species Ctenidium molluscum and Homalothecium sericeum [18], although a modest recovery was observed after 16 days from exposure. Our moss samples did not show any sign of recovery over time, but, specifically, they showed a lower tolerance than lichens to the biocides.

Our results indicated a similar effectiveness of Biotin T and Preventol RI80 against both the lichen and the moss, even if Biotin $\mathrm{T}$ showed a stronger and earlier effect. The effectiveness of these biocides in impairing the photosynthesis is determined by their chemical composition, rich in quaternary ammonium compounds (i.e., didecyl-dimethyl ammonium chloride, DDAC, and BAC, respectively) as active components [16]. They are well-known xenobiotics with a notable algicidal action [35-38], produced by their remarkable capacity to disrupt cell membranes [39], which causes the release of intracellular metabolites and the degradation of proteins and nucleic acids, until cell lysis [40]. In addition, OIT showed a marked efficacy against algae, as reported in toxicity tests using the algae Scenedesmus vacuolatus and Selenastrum capricornutum [26,41], even if following a different mechanism of action (i.e., the blocking of the enzymatic pathway of cysteines in proteins active sites, respiration, ATP synthesis and metabolism) [22,26]. On these bases, we speculate that the quick photosynthetic impairments caused by Biotin T on both E. prunastri and Brachythecium is determined by the joint action of DDAC and OIT on chloroplasts.

The chlorophyll a fluorescence transients of both our model organisms clearly confirmed the dramatic disruption of the energy transmission system of photosystem II after only $24 \mathrm{~h}$ from exposure, without any recovery over time, up to 21 days. This effect is particularly evident when observing the complete lack of the typical fluorescence steps (OJIP) observed in healthy and performing photosynthetic systems (control samples), suggesting a very strong impairment of plastoquinone $A(Q A)$, plastoquinone $B(Q B)$, and a great free plastoquinone (PQ) reduction [42]. Similar results were previously observed for the lichens $X$. parietina, in the lab; and P. muralis, V. nigrescens, and X. tinctina, in the field $[15,16]$. In these latter cases, however, the choice of the application protocol was crucial to determine a complete or incomplete effectiveness of the treatment, indicating some biocide-stress resilience of the species adapted to the lithobiontic lifestyle.

\section{Materials and Methods}

\subsection{Experimental}

Healthy samples of the lichen Evernia prunastri (L.) Ach. and the moss Brachythecium sp. were collected during September 2019 in a rural area of the province of Siena $\left(43^{\circ} 07^{\prime} 31.9^{\prime \prime} \mathrm{N}\right.$ $\left.11^{\circ} 21^{\prime} 38.7^{\prime \prime} \mathrm{E}\right)$, far from any local source of pollution. In the laboratory, samples were ridded of any extraneous material using plastic tweezers and then left overnight at environmental conditions (temperature $=20 \pm 2{ }^{\circ} \mathrm{C}, \mathrm{RH}=65 \pm 5 \%$ ). Although the lichen is an epiphytic species and the moss, reported for heritage sites [43,44], has been not characterized in terms of deteriogenic activity, they were chosen as model organisms considering their ease of collection and handling, and their wide use as bioindicators. Each pool of lichen and moss samples was divided into three batches, loosely wrapped in a plastic net $\left(\right.$ mesh $\left.=1 \mathrm{~cm}^{2}\right)$ and closed at the extremities with a plastic wire (lichen and moss bags). Two out of the three batches of lichen and moss samples were incubated for $1 \mathrm{~h}$ in $3 \%$ Biotin T or $2 \%$ Preventol RI80, respectively, using tap water as solvent (concentrations were those suggested by the 
producer). The remaining batch of lichens and mosses was soaked in tap water and used as control. All treatments were carried out maintaining a constant 200/50 weight/volume ratio [16]. After incubation, all samples were removed from the bags, pat dried using paper towels, and then exposed into the experimental greenhouse of the Botanical Garden of the University of Siena (temperature $=18 \pm 2{ }^{\circ} \mathrm{C}, \mathrm{RH}=70 \pm 5 \%$ ), characterized by complete natural illumination and constant air ventilation. During the experiment, samples were not artificially hydrated. Samples (six for each treatment, statistical replicates) were retrieved after 1,3 , and 21 days.

\subsection{Chemical Characteristics of Biotin T and Preventol RI80}

The Biotin T and Preventol RI80 are both quaternary ammonium compounds (QACs)based biocidal products. Specifically, Biotin T (C.T.S. S.r.1., Altavilla Vicentina, Italy) is composed of didecyl-dimethyl ammonium chloride (DDAC, 40-60\%) and n-octylisothiazolinone (OIT, 7.0-10.0\%), while Preventol RI80 (Lanxess, Köln, Germany) is composed of benzalkonium chloride (i.e., alkyl dimethyl benzyl ammonium chloride, approx. $80 \%$ ) and isopropyl alcohol (2\%). Both these biocidal products are routinely used for the removal of biological colonization from stony monuments through a dilution of $3 \%$ for Biotin T and 2\% for Preventol RI80 [15], using tap or bottled water as solvent.

\subsection{Accumulation of Biocide Compounds}

The accumulation of benzalkonium chloride (BAC) and of n-octyl-isothiazolinone (OIT) in lichen and moss samples were used as indicators of the accumulation of Preventol RI80 and Biotin T, respectively. BAC was selected as the only active ingredient of the relative product, while OIT was chosen because it showed a higher UV absorption than DDAC, despite being less concentrated. Six replicates were used for each treatment.

For the extraction of BAC, samples of $100 \mathrm{mg}$ were homogenized in $2 \mathrm{~mL}$ of deionized water and then centrifugated at 22,000 $\mathrm{g}$ for five minutes. The supernatant was then filtered at $0.45 \mu \mathrm{m}$ using a syringe filter and directly analyzed by HPLC (PerkinElmer's Series 200). Runs were monitored at $223 \mathrm{~nm}$ using a Photo Diode Array (PDA) detector and acetonitrile-sodium acetated buffer $(\mathrm{pH} 5 ; 0.2 \mathrm{M})$ as mobile phase $(70: 30 \mathrm{v} / \mathrm{v})$ [45]. The separation was granted using a C18 Agilent column $(4.6 \mathrm{~mm} \times 250 \mathrm{~cm}, 5 \mu \mathrm{m}$ particle size) For the extraction of OIT, samples of $100 \mathrm{mg}$ were homogenized with $2 \mathrm{~mL}$ of methanol (HPLC grade) and processed as described for BAC extraction. The filtered solution was then analyzed by HPLC (PerkinElmer's Series 200) coupled with a PDA detector, using methanol as mobile phase at the flow rate of $1 \mathrm{~mL} /$ minute. Runs were read at $277 \mathrm{~nm}$. Separations were obtained using an Agilent C18 column $(4.6 \mathrm{~mm} \times 250 \mathrm{~cm}, 5 \mu \mathrm{m}$ particle size). The methodology has been adapted from Rosero-Moreano et al. [46].

The quantification of both BAC and OIT was obtained by means of calibration curves prepared by dissolving the respective standards (abcr $\mathrm{GmbH}$, Germany) in deionized water for BAC (range 9-400 $\mu \mathrm{g} / \mathrm{mL}$ ), and methanol for OIT (range 0.5-50 $\mu \mathrm{g} / \mathrm{mL}$ ). Before analysis, each sample was diluted 10 and 20 times, respectively.

\subsection{Photosynthetic Efficiency}

The efficiency of the photosynthetic system of the lichen E. prunastri and the moss Brachythecium sp. was assessed in terms of chlorophyll content, chlorophyll a fluorescence emission, and spectral reflectance. Fifteen replicates were measured for each experimental unit.

Total chlorophyll content was measured using a chlorophyll content meter (CCM-300, Opti-Science, Hudson, NJ, USA), which provides results on a surface basis $\left(\mathrm{mg} / \mathrm{m}^{2}\right)$. The effectiveness of this instrument for the quantification of the chlorophyll content on both E. prunastri and Brachythecium samples has been investigated by Vannini et al. [47].

The analysis of the chlorophyll a fluorescence was carried out by means of a plant efficiency analyzer fluorimeter (Handy PEA, Hansatech, Norfolk, UK), lightening samples with a red light pulse $\left(1800 \mu \mathrm{mol}\right.$ photons $\left.\mathrm{m}^{2} / \mathrm{s}\right)$ for one second with a light emitting diode 
(LED). Prior to the analysis, all samples were hydrated in a climatic chamber at $16{ }^{\circ} \mathrm{C}$, $90 \% \mathrm{RH}$, and $40 \mu \mathrm{mol} / \mathrm{m}^{2} / \mathrm{s}$ PAR, to obtain their maximal photosynthetic activation.

The spectral reflectance of chlorophyll pigments, which is a measure of plant health and chlorophyll integrity [48], was expressed in terms of normalized difference vegetation index (NDVI), and measurements were carried out using the PlantPen NDVI 310 (Photon System Instruments, Drásov, Czech Republic).

\subsection{Statistical Analysis}

Given the limited dataset, all the statistical analyses were run using non-parametric tests. Differences across time were checked using the pairwise Wilcoxon signed-rank test, correcting for multiple testing according to Benjamini and Hochberg [49]. Differences between treated and control samples were sought by the Mann-Whitney $U$ test. Since control values of photosynthetic parameters showed statistically significant differences across time, the results of treated samples were normalized for their respective control values and expressed as treated-to-control ratios. All the statistical analyses were run using R software [50].

\section{Conclusions}

The gradual replacement of the use of traditional biocides with alternative control strategies, in compliance with the European Green Deal directive, should point to an unaltered or even higher effectiveness to contrast biodeterioration issues. This study highlights the severe impairment of the photosynthetic apparatus and the absence of recovery (up to 21 days) caused in the lichen E. prunastri and the moss Brachythecium sp. by BAC and OIT (i.e., active compounds of traditional biocides), which were accumulated in thalli in similar amounts. The response of these model species, which are, however, more biocide-sensitive than others specifically adapted to the to the lithobiontic lifestyle, should be regarded as a benchmark for "green" alternatives to traditional biocides, which should be preliminarily tested under the proposed controlled conditions before moving to the indispensable, but more challenging, in situ assay.

Author Contributions: S.L. and A.V. conceived and designed the experiments; G.C. and A.V. performed the experiments; A.V. and S.L. analyzed the data; A.V. wrote the paper; S.L. and S.E.F.-L. supervised the text. All authors have read and agreed to the published version of the manuscript.

Funding: This research received no external funding.

Institutional Review Board Statement: Not applicable.

Informed Consent Statement: Not applicable.

Data Availability Statement: Data is contained within the article.

Conflicts of Interest: The authors declare no conflict of interest.

\section{References}

1. Favero-Longo, S.E.; Viles, H.A. A review of the nature, role and control of lithobionts on stone cultural heritage: Weighing-up and managing biodeterioration and bioprotection. World J. Microbiol. Biotechnol. 2020, 36, 1-18. [CrossRef]

2. Caneva, G.; Nugari, M.P.; Nugari, M.P.; Salvadori, O. Plant Biology for Cultural Heritage: Biodeterioration and Conservation; Getty Publications: Los Angeles, CA, USA, 2008.

3. Dakal, T.C.; Cameotra, S.S. Microbially induced deterioration of architectural heritages: Routes and mechanisms involved. Environ. Sci. Eur. 2012, 24, 36. [CrossRef]

4. Salvadori, O.; Casanova-Municchia, A. The role of fungi and lichens in the biodeterioration of stone monuments. Open Conf. Proc. J. 2016, 7. [CrossRef]

5. Saiz-Jimenez, C.; Garcia Rowe, J.; Rodriguez Hidalgo, J.M. Biodeterioration of polychrome Roman mosaics. Int. Biodeterior. Biodegrad. 1991, 28, 65-79. [CrossRef]

6. Altieri, A.; Ricci, S. Calcium uptake in mosses and its role in stone biodeterioration. Int. Biodeterior. Biodegrad. 1997, 40, 201-204. [CrossRef]

7. Kumar, R.; Kumar, A.V. Biodeterioration of Stone in Tropical Environments: An Overview; Getty Publications: Los Angeles, CA, USA, 1999. 
8. Ricci, S.; Altieri, A. Il ruolo delle briofite nel deterioramento dei Beni Culturali. In Biologia ed Ecologia Delle Briofite; Aleffi, M., Ed.; Antonio Delfino: Roma, Italia, 2008; pp. 417-434.

9. Caneva, G.; Terscari, M. Stone biodeterioration: Treatments and preventive conservation. In Proceedings of the 2017 International Symposium of Stone Conservation, Conservation Technologies for Stone Cultural Heritages: Status and Future Prospects, Seoul, Korea, 21 September 2017; National Research Institute of Cultural Heritage of Korea: Daejeon, Korea, 2017; pp. 95-114.

10. Lo Schiavo, S.; De Leo, F.; Urzì, C. Present and future perspectives for biocides and antifouling products for stone-built cultural heritage: Ionic liquids as a challenging alternative. Appl. Sci. 2020, 10, 6568. [CrossRef]

11. Kakakhel, M.A.; Wu, F.; Gu, J.D.; Feng, H.; Shah, K.; Wang, W. Controlling biodeterioration of cultural heritage objects with biocides: A review. Int. Biodeterior. Biodegrad. 2019, 143, 104721. [CrossRef]

12. Monte, M.; Nichi, D. Effects of two biocides in the elimination of lichens from stone monuments: Preliminary findings. Sci. Technol. Cult. Herit. 1997, 6, 209-216.

13. Tretiach, M.; Bertuzzi, S.; Salvadori, O. Chlorophyll a fluorescence as a practical tool for checking the effects of biocide treatments on endolithic lichens. Int. Biodeterior. Biodegrad. 2010, 64, 452-460. [CrossRef]

14. De los Ríos, A.; Pérez-Ortega, S.; Wierzchos, J.; Ascaso, C. Differential effects of biocide treatments on saxicolous communities: Case study of the Segovia cathedral cloister (Spain). Int. Biodeterior. Biodegrad. 2012, 67, 64-72. [CrossRef]

15. Favero-Longo, S.E.; Benesperi, R.; Bertuzzi, S.; Bianchi, E.; Buffa, G.; Giordani, P.; Loppi, S.; Malaspina, P.; Matteucci, E.; Paoli, L.; et al. Species- and site-specific efficacy of commercial biocides and application solvents against Lichens. Int. Biodeterior. Biodegrad. 2017, 123, 127-137. [CrossRef]

16. Vannini, A.; Contardo, T.; Paoli, L.; Scattoni, M.; Favero-Longo, S.E.; Loppi, S. Application of commercial biocides to lichens: Does a physiological recovery occur over time? Int. Biodeterior. Biodegrad. 2018, 129, 189-194. [CrossRef]

17. Favero-Longo, S.E.; Vannini, A.; Benesperi, R.; Bianchi, E.; Fačkovcová, Z.; Giordani, P.; Malaspina, P.; Martire, L.; Matteucci, E.; Paoli, L.; et al. The application protocol impacts the effectiveness of biocides against lichens. Int. Biodeterior. Biodegrad. 2020, 155, 105105. [CrossRef]

18. Bertuzzi, S.; Candotto Carniel, F.; Pipan, G.; Tretiach, M. Devitalization of poikilohydric lithobionts of open-air monuments by heat shock treatments: A new case study centred on bryophytes. Int. Biodeterior. Biodegrad. 2013, 84, 44-53. [CrossRef]

19. Zykubek, K.; Proudfoot, T.; Lithgow, K.; Carpenter, D. Research on the selection of biocides for the 'disinfection' of statues and masonry at the National Trust (UK). J. Inst. Conserv. 2020, 43, 225-241. [CrossRef]

20. Seaward, M.R.D. Lichens as Agents of Biodeterioration. In Recent Advances in Lichenology; Upreti, D.K., Divakar, P.K., Shukla, V., Bajpai, R., Eds.; Springer: New Delhi, India, 2015; Volume 1. [CrossRef]

21. Richardson, B.A. Control of microbial growth on stone and concrete. In Biodeterioration; Houghton, D.R., Smith, R.N., Eggins, H.O.W., Eds.; Elsevier Applied Science: London, UK; New York, NY, USA, 1988; Volume 7, pp. 101-106.

22. Williams, T.M. The Mechanism of Action of Isothiazolone Biocide; CORROSION: San Diego, CA, USA, 2006.

23. Tezel, U.; Pavlostathis, S.G. Quaternary ammonium disinfectants: Microbial adaptation, degradation and ecology. COBIOT 2015, 33, 296-304. [CrossRef] [PubMed]

24. Tomaselli, L.; Lamenti, G.; Tiano, P. Chlorophyll fluorescence for evaluating biocide treatments against phototrophic biodeteriogens. Anal. Microbial. 2002, 52, 197-206.

25. Khan, A.H.; Libby, M.; Winnick, D.; Palmer, J.; Sumarah, M.; Ray, M.B.; Macfie, S.M. Uptake and phytotoxic effect of benzalkonium chlorides in Lepidium Sativum and Lactuca Sativa. J. Environ. Manag. 2018, 206, 490-497. [CrossRef]

26. Silva, V.; Silva, C.; Soares, P.; Garrido, E.M.; Borges, F.; Garrido, J. Isothiazolinone biocides: Chemistry, biological, and toxicity profiles. Molecules 2020, 25, 991. [CrossRef]

27. Collier, P.J.; Ramsey, A.J.; Austin, P.; Gilbert, P. Growth inhibitory and biocidal activity of some isothiazolone biocides. J. Appl. Bacteriol. 1990, 69, 569-577. [CrossRef]

28. Diehl, M.A.; Chapman, J.S. Association of the biocide 5-chloro-2-methyl-isothiazol-3-one with Pseudomonas Aeruginosa and Pseudomonas fluorescens. Int. Biodeterior. Biodegrad. 1999, 44, 191-199. [CrossRef]

29. García, M.R.; Cabo, M.L. Optimization of E. coli inactivation by benzalkonium chloride reveals the importance of quantifying the inoculum effect on chemical disinfection. Front. Microbiol. 2018, 9, 1259. [CrossRef] [PubMed]

30. Jovović, M.; Kostić, N.; Jančić-Stojanović, B.; Malenović, A. Investigation of tropicamide and benzalkonium chloride stability using liquid chromatography. J. Liq. Chromatogr. R. T. 2012, 35, 231-239. [CrossRef]

31. Patrauchan, M.A.; Oriel, P.J. Degradation of benzyldimethylalkylammonium chloride by Aeromonas hydrophila sp. K. J. Appl. Microbiol. 2003, 94, 266-272. [CrossRef] [PubMed]

32. He, Z.-W.; Liu, W.-Z.; Tang, C.-C.; Liang, B.; Guo, Z.-C.; Wang, L.; Ren, Y.-X.; Wang, A.-J. Performance and microbial community responses of anaerobic digestion of waste activated sludge to residual benzalkonium chlorides. Energy Convers. Manag. 2019, 202, 112211. [CrossRef]

33. Pereira, B.P.M.; Tagkopoulos, I. Benzalkonium chlorides: Uses, regulatory status, and microbial resistance. Appl. Environ. Microbiol. 2019, 85. [CrossRef]

34. Bollmann, U.E.; Fernández-Calviño, D.; Brandt, K.K.; Storgaard, M.S.; Sanderson, H.; Bester, K. Biocide runoff from building facades: Degradation kinetics in soil. Environ. Sci. Technol. 2017, 51, 3694-3702. [CrossRef]

35. Jing, G.; Zhou, Z.; Zhuo, J. Quantitative structure-activity relationship (QSAR) study of toxicity of quaternary ammonium compounds on Chlorella pyrenoidosa and Scenedesmus quadricauda. Chemosphere 2012, 86, 76-82. [CrossRef] 
36. DeLeo, P.C.; Huynh, C.; Pattanayek, M.; Schmid, K.C.; Pechacek, N. Assessment of ecological hazards and environmental fate of disinfectant quaternary ammonium compounds. Ecotox. Environ. Saf. 2020, 206, 111116. [CrossRef]

37. Zhang, C.; Cui, F.; Zeng, G.; Jiang, M.; Yang, Z.; Yu, Z.; Zhu, M.; Shen, L. Quaternary ammonium compounds (QACs): A review on occurrence, fate and toxicity in the environment. Sci. Total Environ. 2015, 518, 352-362. [CrossRef]

38. Nowicka-Krawczyk, P.; Kosiróg, A.; Otlewska, A.; Rajkowska, K.; Piotrowska, M. Multistep approach to control microbial fouling of historic building materials by aerial phototrophs. Biofouling 2019, 35, 284-298. [CrossRef]

39. McDonnel, G.; Russel, A.D. Antiseptics and Disinfectants: Activity, Action, and Resistance. Clin. Microb. Rev. 1999, 12, 147-179. [CrossRef]

40. Salton, M.R.J. Lytic agents, cell permeability, and monolayer penetrability. J. Gen. Physiol. 1968, 52, 227-252. [CrossRef] [PubMed]

41. EPA. Reregistration Eligibility Decision for 2-Octyl-3 (2H)-isothiazolone (OIT). 2007. Available online: https://archive.epa.gov / pesticides/reregistration/web/pdf/octhilinone-red.pdf (accessed on 4 January 2021).

42. Küpper, H.; Benedikty, Z.; Morina, F.; Andresen, E.; Mishra, A.; Trtílek, M. Analysis of OJIP chlorophyll fluorescence kinetics and $\mathrm{Q}$ A reoxidation kinetics by direct fast imaging. Plant Physiol. 2019, 179, 369-381. [CrossRef] [PubMed]

43. Steinbauer, M.J.; Gohlke, A.; Mahler, C.; Schmiedinger, A.; Beierkuhnlein, C. Quantification of wall surface heterogeneity and its influence on species diversity at medieval castles-implications for the environmentally friendly preservation of cultural heritage. J. Cult. Herit. 2013, 14, 219-228. [CrossRef]

44. Elharech, M.; Benharbit, M.; Magri, N.; Benharbit, O.; Zidane, L.; Douira, A.; Dahmani, J. Study of the bryological flora at the archaeological site of Chellah, Morocco. Int. J. Environ. Agric. Biotechnol. 2017, 2, 238834. [CrossRef]

45. Rojsitthisak, P.; Wichitnithad, W.; Pipitharome, O.; Sanphanya, K.; Thanawattanawanich, P. Simple HPLC determination of benzalkonium chloride in ophthalmic formulations containing antazoline and tetrahydrozoline. PDA J. Pharm. Sci. Technol. 2005, 59, 332-337. [PubMed]

46. Rosero-Moreano, M.; Canellas, E.; Nerín, C. Three-phase hollow-fiber liquid-phase microextraction combined with HPLC-UV for the determination of isothiazolinone biocides in adhesives used for food packaging materials. J. Sep. Sci. 2014, 37, 272-280. [CrossRef]

47. Vannini, A.; Canali, G.; Pica, M.; Nali, C.; Loppi, S. The water content drives the susceptibility of the lichen Evernia prunastri and the moss Brachythecium sp. to high ozone concentrations. Biology 2020, 9, 90. [CrossRef]

48. Castro, K.L.; Sanchez-Azofeifa, G.A. Changes in spectral properties, chlorophyll content and internal mesophyll structure of senescing Populus balsamifera and Populus tremuloides leaves. Sensors 2008, 8, 51-69. [CrossRef]

49. Benjamini, Y.; Hochberg, Y. Controlling the false discovery rate: A practical and powerful approach to multiple testing. J. R. Stat. Soc. Series B Methodol. 1995, 57, 289-300. [CrossRef]

50. R Core Team. R: A Language and Environment for Statistical Computing; R Foundation for Statistical Computing: Vienna, Austria, 2020; Available online: http:/ / www.r-project.org/index.html (accessed on 27 December 2020). 